Maryam NAGHIBI

Mohsen FAIZI

Ahmad EKHLASSI

\title{
The role of user preferences in urban acupuncture: Reimagining leftover spaces in Tehran, Iran
}

The article deals with the fragile connection that public spaces often have with their context. In this regard, the use of urban acupuncture in leftover space can be an opportunity to revitalize the urban fabric through small-scale interventions developed in accordance with community preferences. This study evaluates interventions in vacant plots based on both residents' preferences and experts' opinions. Using the example of leftover space in Tehran, this article explores public preferences and priorities regarding urban acupuncture from a social, design, and aesthetic perspective, applying a descriptive-analytical method. The opinions of six experts were examined and categorized in the first phase. In the second phase, the topics and subtopics extracted from the first phase were incorporated into visual questionnaires to evaluate preferences, from which 165 valid responses were obtained. Following the analysis of the questionnaires, twenty-two personal interviews were carried out. The results show which interventions are preferred over others.

Keywords: leftover spaces, urban acupuncture, urban intervention, user preferences, Iran 


\section{Introduction}

Leftover spaces are part of infrastructure that can improve social situations and ecological conditions (Kremer et al., 2013), and they present an alternative to contemporary public spaces (Kamvasinou, 2011). In addition, a better appreciation of the public value of urban vacant land is vital for better understanding its value in terms of ecological and social benefits (Kim, 2016). In order to convert unsafe areas and aesthetically displeasing landscapes into opportunities for enhancing social and ecological systems (Folke, 2006; Wals \& Wals, 2015), there is still a need for research on how to intervene in social and environmental conditions, management practices, land uses, and vacant land (Kremer et al., 2013).

The primary advantage of community involvement in regenerating leftover spaces is that the final design of areas reflects residents' concerns and ideas (Kim et al., 2020). Despite the importance of developing effective engagement strategies to increase public support for redeveloping leftover spaces, much remains to be investigated regarding public attitudes toward vacant land (Kim \& Miller, 2017). From this perspective, applying the urban acupuncture approach to vacant land can present a convenient opportunity to reduce social challenges. Modern cities often have to be designed with macro-structural interventions (Kermani, 2016), leading to high vacancy rates in cities with social challenges (Zhang et al., 2019). Urbanism focuses on the micro experiences of urban spaces. Urban acupuncture provides a macro lens and produces small-scale but ecologically and socially catalytic development in the built environment (Casagrande, 2015). Moreover, future cities will face limited urban spaces and resources. In this regard, vacant land is an opportunity (Németh \& Langhorst, 2014; Dubeaux \& Cunningham Sabot, 2018) that can be transformed into useful space (Newman et al., 2018) to balance and stabilize neighbourhoods. In the twentieth century, leftover spaces were mostly seen as voids in the urban structure (Newman \& Kim, 2017). Today, voids are constitutive elements of urban structure, and the magnitude of the impact of small-intervention designs as urban acupuncture is evaluated for a precise function (Kim, 2016). Because studies of abandoned spaces refer to users' key roles and preferences (Lynch, 1977; Trancik, 1986; Thompson, 2002), considering these preferences is useful in choosing the type of intervention. The gap between theory and practice has been noted for some time. Thus, this study addresses an area developed in Tehran. To improve the relationship between urban intervention characteristics and residents' priorities in Tehran, leftover spaces have been identified as an opportunity for urban revival.
The following paragraphs provide the theoretical background to examine what the significant intervention factors are in people's priorities and preferences regarding residual spaces. This study therefore investigates user preferences and priorities to enhance the relationship between urban intervention characteristics and community preference in public spaces. First, a literature review is provided, followed by a presentation of the materials and methods used and the main findings. The conclusion discusses the key findings concerning the central research question and recommendations for future research.

\section{Literature review}

Understanding the role of vacant land as a potentially valuable natural and community asset can improve environmental quality in the surrounding neighbourhood (Kim, 2016). Leftover spaces have been defined very differently: as cracks in the urban structure (Loukaitou-Sideris, 1996), undesirable urban areas (Trancik, 1986), no man's land (Mariani \& Barron, 2014), vacant land and unoccupied places available for spontaneous utilization (Lokman, 2017), and urban voids (Newman \& Kim, 2017), which are perceived as public spaces (Kamvasinou, 2011; Kim, 2016).

According to de Solà-Morales (2014), vacancy constitutes strange places with spatial disorder potential, leading to new spatial qualities (Mariani \& Barron, 2014). Nevertheless, an entirely unregulated environment would encourage improper social behaviour (Unt et al., 2014). However, a growing body of literature suggests that the regeneration of leftover spaces may lead to logical and inevitable courses of activity (Drake \& Lawson, 2014; Pearsall \& Lucas, 2014) for various applications, such as recreational areas (Johnson et al., 2014). Having become detached from their previous functions, these spaces have become open and empty, waiting to be filled with new utilization (Franck \& Stevens, 2007). De Solà-Morales (2014) suggested empty places as the evocative potential of the city. They are latent places with special qualities that should be understood and respected to create predictable designs (Armstrong, 2006).

There is an assumption in the twenty-first century that claims cities' minimal interventions are the most relevant design strategies of urban development (Enia \& Martella, 2019). In this regard, the concept of urban acupuncture presents small-scale interventions (Colorni et al., 2017). Urban acupuncture is a new way of understanding the catalysis of urban regeneration (Casanova \& Hernandez, 2015). It is a strategy for approaching urban renewal or development projects to address social, ecological, and environmental issues (Daugelaite et al., 2018) and create shared common spaces for the local population. 
Table 1: Features of intervention.

\begin{tabular}{ll}
\hline Feature & References \\
\hline $\begin{array}{l}\text { Small scale micro-inter- } \\
\text { vention }\end{array}$ & $\begin{array}{l}\text { Marzi \& Ancona, 2004; Acebillo, 2006; Cheng \& Niu, 2010; Radstaak, 2012; Casagrande, 2015; Aouad, 2016; } \\
\text { Campelo \& Fontenele, 2017; Colorni et al., 2017; Grifoni et al., 2017; Bugaric, 2018; Cerro, 2018; Daugelaite et al., } \\
\text { 2018; Rau \& Hutchison, 2019 }\end{array}$ \\
\hline Accuracy & Shieh, 2006; Campelo \& Fontenele, 2017 \\
\hline $\begin{array}{l}\text { Catalytic for the entire } \\
\text { surroundings }\end{array}$ & $\begin{array}{l}\text { Shieh, 2006; Cheng \& Niu, 2010; de Solà-Morales 2014; Campelo \& Fontenele, 2017; Colorni et al., 2017; Grifoni } \\
\text { et al., 2017 }\end{array}$ \\
\hline Quick implementation & Marzi \& Ancona, 2004; Colorni et al., 2017; Enia \& Martella, 2019 \\
\hline Low cost & Cheng \& Niu, 2010; Rau \& Hutchison, 2019 \\
\hline Bottom-up & Unt \& Bell, 2014; Gadanho, 2015; Aouad, 2016; Campelo \& Fontenele, 2017; Bugaric, 2018 \\
\hline Local & Tortosa et al., 2010; De Wit, 2014; Unt \& Bell, 2014; Casagrande, 2015; Houghton et al., 2015; Aouad, 2016; \\
\hline Tactical & Unt \& Bell, 2014; Casagrande, 2015; Gadanho, 2015; Houghton et al., 2015; Aouad, 2016; Lastra \& Pojani, 2018 \\
\hline
\end{tabular}

Community engagement is a crucial part of urban planning and design because previous studies emphasize that different urban design guidelines are required by local needs and aspirations (Polat \& Tümer Yıldız, 2019). Because urban acupuncture interventions consider residents' involvement, this strategy can address social aspects. Moreover, the application of urban acupuncture follows the strategy of well-targeted and minimal interventions (Daugelaite et al., 2018) considering residents' needs and their perspectives to change public space and improve residents' quality of life (Bugaric, 2018). A wide range of urban acupuncture examples can be found, from introducing a new tradition to changing habits (Lerner, 2014), which landscape architects and urban planners can use as a model to improve residents' quality of life. The design perspective of urban spaces seeks to create an observable organizing structure and a sense of human scale (Behzadfar et al., 2014). In this regard, numerous authors argue that producing smart and small interventions in a given site can positively affect the surroundings (Lydon et al., 2015). Having claimed that they are "interventions" in the built environment, Frampton believed that new projects have a moral obligation to catalyse the renovation of their surroundings (Shieh, 2006). This approach has been recognized as important in urban managed environments, with an emphasis on natural dynamics and low implementation costs (Daugelaite et al., 2018). It is beneficial in the developing world, where governments and institutions have limited resources, and it increases the direct participation of those living in such areas.

Acupunctural interventions in urban spaces create more comprehensive changes than initially intended (Lydon et al., 2015; Lastra \& Pojani, 2018). Employing the "right measure" architectural approach to interventions, appropriate and necessary adjustments can be made to a place (Enia \& Martella, 2019). Based on the literature review, small-scale interventions in urban spaces, such as spaces between blocks, building frontages, pocket parks, and small pieces of vacant land, should have specific features, which are presented in Table 1.

The main benefit of community involvement in regenerating leftover spaces is that the final design areas reflect residents' preferences, and so it is useful to increase such involvement (Kim et al., 2020). Despite the significance of developing effective engagement strategies to increase public support for redeveloping leftover spaces, there is still a lack of research on public attitudes toward vacant land (Kim \& Miller, 2017). Past perception research on landscapes and sites has generally focused on environmental characteristics that influence landscape perception (Lafortezza et al., 2008; Hofmann et al., 2012; Svobodova et al., 2012; Ruelle et al., 2013). Several recent studies have suggested the integration of visual preferences with ecological site rehabilitation (Hands \& Brown, 2002; Tveit et al., 2006) and landscape planning and design (Ahern, 1999; Greenberg \& Lewis, 2000; Ruelle et al., 2013), but the investigation remains mostly untested in leftover spaces. Visual preference evaluation is a significant factor in evaluating residents' acceptance and desire to participate in the urban modernization intervention process (Zhao et al., 2020). Although a photo display has certain limitations (Daniel, 2001; Palmer \& Hoffman, 2001; Steinitz, 2001), it is a significant public visual preference evaluation method.

\section{Materials and methods}

\subsection{Study area}

Although public spaces in Tehran are not very user-friendly, they possess porous characteristics that make possible embodiments of place bearing spontaneous events and experiences (Khorshidifard, 2014). Despite the scenarios of responsible organizations to enhance environmental quality and develop green spaces, the city has not been able to restore its ecolog- 


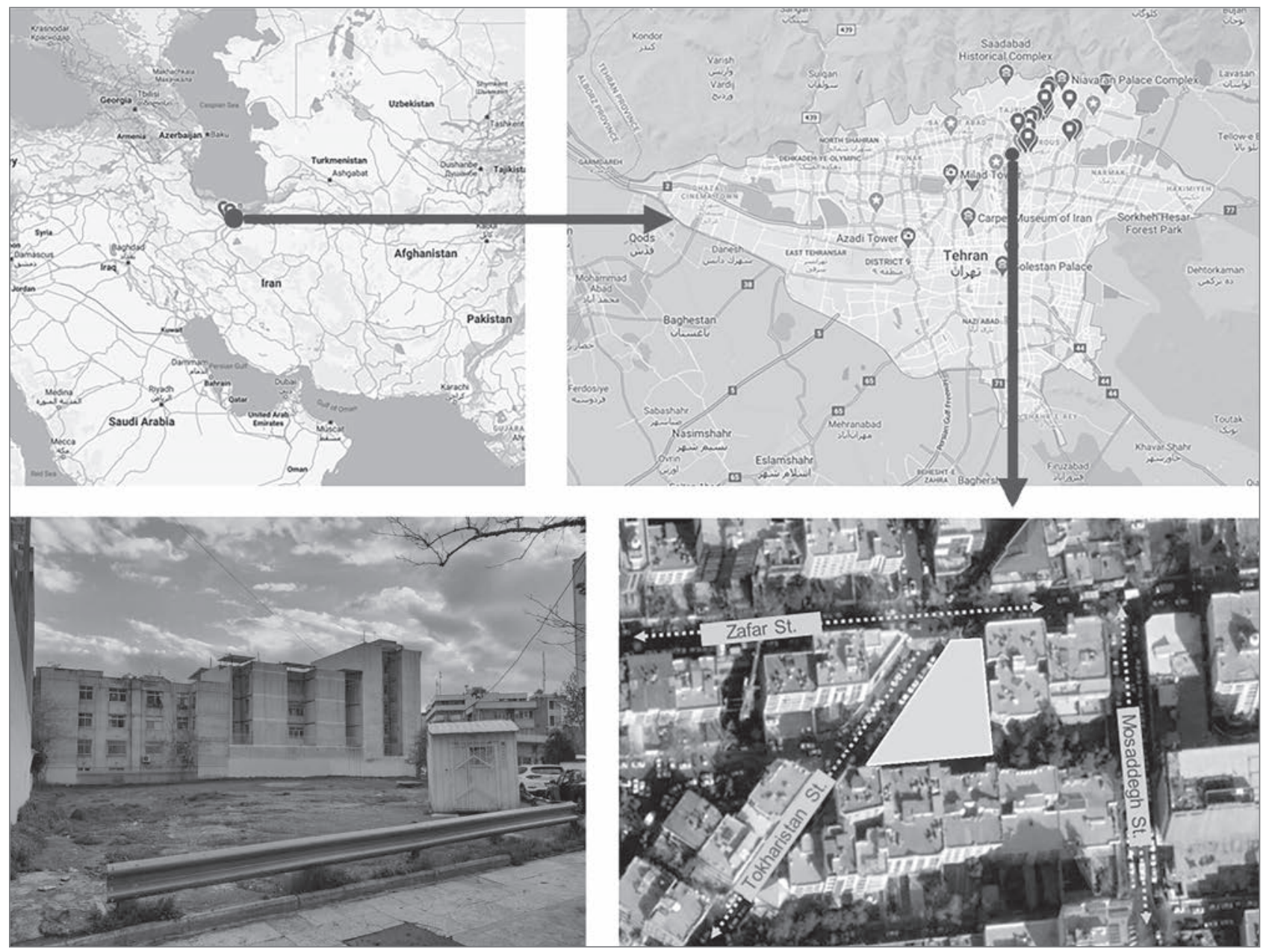

Figure 1: Site location (illustration: authors; source: Mapdata 2020).

\subsection{Research methodology}

ical network due to fragmentation resulting from unplanned growth (Bahrami et al., 2012). Because of the demolition of valuable natural structures in Tehran, numerous problems have arisen. Moreover, because Tehran is a metropolitan city that suffers from limited space, considering urban acupuncture in leftover areas can be useful. The diversity of leftover spaces in Tehran encouraged the researchers to choose this city as a study area. Due to the available facilities and to improve possible projects through public involvement, the main idea behind this study was to investigate urban acupuncture interventions on micro-leftover areas in Tehran. The criteria for selecting this case study included small open, empty, and underused spaces in residential neighbourhoods. Preliminary interviews were conducted with residents to select a site as a leftover space. The study area is located in Zafar, a neighbourhood in northern Tehran with a population of 70,677. As shown in Figure 1, this site is bounded to the north by Zafar Street and to the west by Tokharistan Street.
Research was carried out in several stages. First, photos of urban interventions were chosen from various urban spaces, which could be redesigned for the selected leftover space. Second, the selected scenes were classified into three categories: social, design, and aesthetic. Then each expert was asked individually to select three photographs that best represented each scene's categories and subcategories. In the end, an AHP-based visual questionnaire was conducted to determine residents' preferences.

The AHP decision-making method is used when there are several evaluation factors to complicate the decision-making process. This gives decision-makers a thorough understanding of issues in specific situations for a non-independent "hierarchical structure" (Nekhay \& Arriaza, 2016; Saaty \& De Paola, 2017). It is crucial to achieve a hierarchy among different interventions in micro-leftover areas and to distinguish the key factors that influence residents' preferences in public spaces. This strategy will help measure the effects of improvements at both the neighbourhood and urban scales (Mondini et al., 


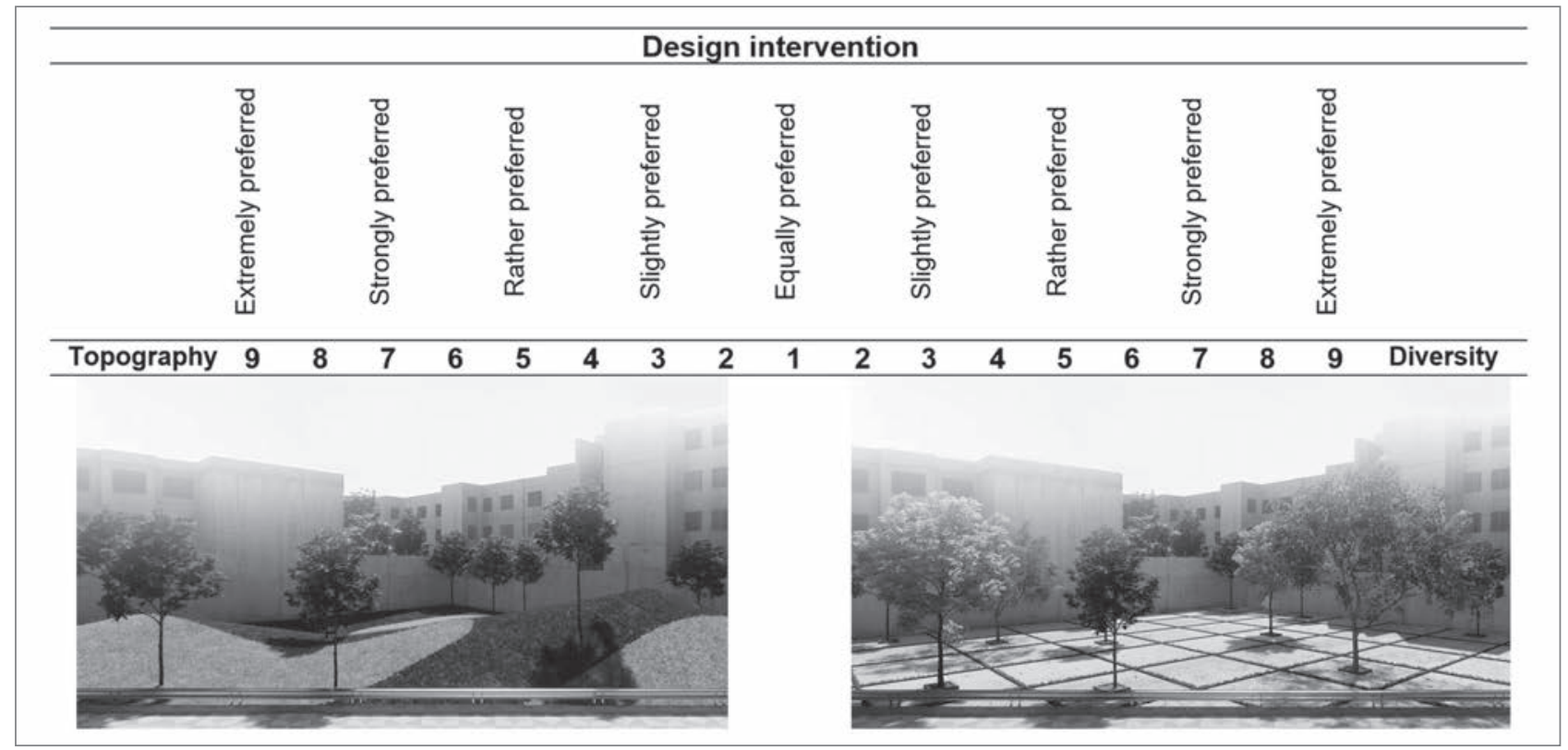

Figure 2: Example of pair comparison in AHP (adapted from Peng, 2019).

Table 2: Hierarchical structure of assessment factors.

\begin{tabular}{|c|c|c|}
\hline Goal & $\begin{array}{l}\text { Assessment } \\
\text { category }\end{array}$ & Sub-category \\
\hline \multirow{17}{*}{$\begin{array}{l}\text { Urban } \\
\text { intervention }\end{array}$} & \multirow{7}{*}{ Social } & Relaxing, restorative \\
\hline & & Playground \\
\hline & & Leisure in a café \\
\hline & & Gallery \\
\hline & & Table-top games \\
\hline & & Sitting \\
\hline & & Exercising \\
\hline & \multirow{5}{*}{ Design } & Topography \\
\hline & & Regular \\
\hline & & Diversity \\
\hline & & Density \\
\hline & & Irregular \\
\hline & \multirow{5}{*}{ Aesthetic } & Colour \\
\hline & & Pattern \\
\hline & & Sculpture \\
\hline & & Installation \\
\hline & & Mural \\
\hline
\end{tabular}

2018). After the online questionnaires were distributed among residents, an online interview was conducted with twenty-two residents.

\subsection{Survey design}

In the first phase, the researchers chose 114 photos of urban interventions in various urban spaces that could be redesigned for the selected leftover space. In order to aid the researchers in the decision-making process for the photo selection, six experts
Table 3: Demographic characteristics of interviewees.

\begin{tabular}{lllll}
\hline & & \multicolumn{3}{c}{ Sex } \\
\hline \multirow{3}{*}{ Age } & Female & Male & Total \\
\cline { 2 - 5 } & $20-40$ & 9 & 8 & 17 \\
\cline { 2 - 5 } & $41-60$ & 2 & 1 & 3 \\
\cline { 2 - 5 } Total & $>60$ & 1 & 1 & 2 \\
\hline
\end{tabular}

with at least nine years of related experience (including three architects, one urban designer, and two landscape architects) were asked to select the scenes that best represented the acupuncture features based on the definitions in Table 1. In the first round, seventy-two scenes were selected. The frequency of the scenes most often selected by the experts was recorded. Features with a frequency of about four times were selected.

As shown in Table 2, these seventy-two selected scenes were classified into the three categories mentioned above. Then, the form of simulation employed to depict changes in the neighbourhood (Norouzian-Maleki et al., 2018) and each of the experts' selected interventions was modelled with the SketchUp software. The AHP method was used to select the appropriate interventions for the leftover space. The first section of the questionnaire comprised residents' demographics characteristics (Table 3) and current place of residence to ensure the respondents were local people. The second section included visual preference with an AHP-based assessment of thirty-seven questions, which the respondents were asked to rate on a seventeen-point rating scale. 
Table 4: Respondents' demographic characteristics.

\begin{tabular}{|c|c|c|c|c|c|c|c|c|}
\hline & & \multicolumn{2}{|c|}{ Sex } & \multicolumn{5}{|c|}{ Occupation } \\
\hline & & Female & Male & Employed & Housewife & Student & Retired & Unemployed \\
\hline \multirow{3}{*}{ Age } & $20-40$ & 78 & 51 & 12 & 10 & 29 & 1 & 77 \\
\hline & $41-60$ & 10 & 11 & 2 & 1 & 1 & 5 & 12 \\
\hline & $>60$ & 6 & 9 & 1 & 2 & 0 & 7 & 5 \\
\hline Total & & 94 & 71 & 15 & 13 & 30 & 13 & 94 \\
\hline
\end{tabular}

Table 5: Relation between education and participation in urban intervention.

\begin{tabular}{llll}
\hline \multirow{3}{*}{ Education } & & Education & Participation \\
\cline { 2 - 4 } & Correlation & 1 & $-.164^{*}$ \\
\cline { 2 - 4 } & Sig. (two-tailed) & .035 \\
& $n$ & 165 & 165 \\
\hline
\end{tabular}

Note: *Correlation is significant at the 0.05 level (two-tailed)

\subsection{Data collection}

To assess the relationship between urban intervention characteristics and community preferences, this study used an AHPbased visual survey. Before adopting the final full-scale study, additional pilot testing was performed to refine the attributes. The respondents were selected using a snowball technique. The online questionnaires were distributed among residents during April and May 2020. A message was randomly sent to two hundred residents, asking them to complete the online questionnaire. The analysis was performed based on the data collected from the survey using Excel, SPSS, and expert-chosen software. The results were rated and presented in the form of descriptive and inferential statistics. Afterward, qualitative data from an open-ended survey were used to complement the study.

A personal online interview was also conducted with twenty-two resident participants to determine residents' preferences for the three categories of urban interventions. The age and sex distribution of the respondents was representative. Therefore, the interviewees were selected following random routes (similar to stratified sampling). Using this process, twelve women and ten men were interviewed with the age distribution in Table 3. Each interview took approximately fifteen to twenty minutes, and the results are described separately in each section.

\section{Results and discussion}

One hundred sixty-five valid responses were selected out of 189 received. Then, ninety-four women and seventy-one men responded to the questionnaire with the following distribution of demographic characteristics as presented in Table 4 .

\subsection{Results of the first section of the survey}

This research investigated the correlation between education, usage, and participation in urban interventions. Using a correlation rank $(p<0.05)$, it was demonstrated that the more educated a person, the more he or she intends to participate in urban interventions. Thus, Table 5 presents the correlation between participation in urban intervention and education.

Urban acupuncture is a bottom-up approach, and so this study also asked about respondents' willingness to participate in developing their neighbourhood. As shown in Table 6, a large number of respondents spend their free time in public spaces, one to two days per week, and they are also more likely to participate in the design intervention of the space: $86.6 \%$ of residents would like to be involved in creating their surrounding environment, and only $6.6 \%$ would not like to be involved in creating their living environment.

Based on Figure 3, the most common activity is walking (63.63\%), followed by connecting with nature (52.12\%), leisure in a café or restaurant (48.48\%), and sitting and relaxing (44.84\%). Walking and connecting with nature seem suitable because most participants were unemployed. Attending events (6.66\%) and leisure with children (9.69\%) are mostly restricted due to crowded environments.

\subsection{Results of the second section of the survey}

The weight per intervention type was derived and presented through AHP and pictures from pairwise comparison per scene, respectively (Tables 7-9). In this regard, assuming the criteria and $w$, which represents the scores on a nine-point scale, the next pairwise comparison matrix is defined as below:

$$
\left(\begin{array}{cccc}
w_{1} / w_{1} & w_{1} / w_{2} & \ldots & w_{1} / w_{n} \\
w_{2} / w_{1} & w_{2} / w_{2} & \ldots & w_{2} / w_{n} \\
\ldots & \ldots & \ldots & \ldots \\
w_{n} / w_{1} & w_{n} / w_{2} & \ldots & w_{n} / w_{n}
\end{array}\right) \times\left(\begin{array}{c}
w_{1} \\
w_{2} \\
\ldots \\
w_{n}
\end{array}\right)=\left(\begin{array}{c}
w_{1} \\
w_{2} \\
\ldots \\
n w_{n}
\end{array}\right)
$$

The solution for a numerically analysed eigenvalue was applied to obtain the relative weight for each subcategory, thus acquiring the maximum eigenvalue $\left(\lambda_{\max }\right)$ of the comparison matrix and the corresponding eigenvector. Saaty (1990) introduced the use of a consistency test on pairwise evaluation as follows: 
Table 6: Correlation between residents' willingness to participate in design interventions.

\begin{tabular}{llllll}
\hline \multicolumn{7}{l}{ Usage (days per week) } & & & Total \\
\hline Participation & $>4$ & $3-4$ & $1-2$ & 2 & 11 \\
\hline Difficult to say & 1 & 3 & 5 & 3 & 11 \\
\hline Don't want to at all & 1 & 3 & 4 & 13 & 73 \\
\hline Somewhat inclined & 8 & 7 & 45 & 26 & 70 \\
\hline Very much want to & 12 & 7 & 97 & & 165 \\
\hline Total & 22 & 20 & & & 26 \\
\hline
\end{tabular}

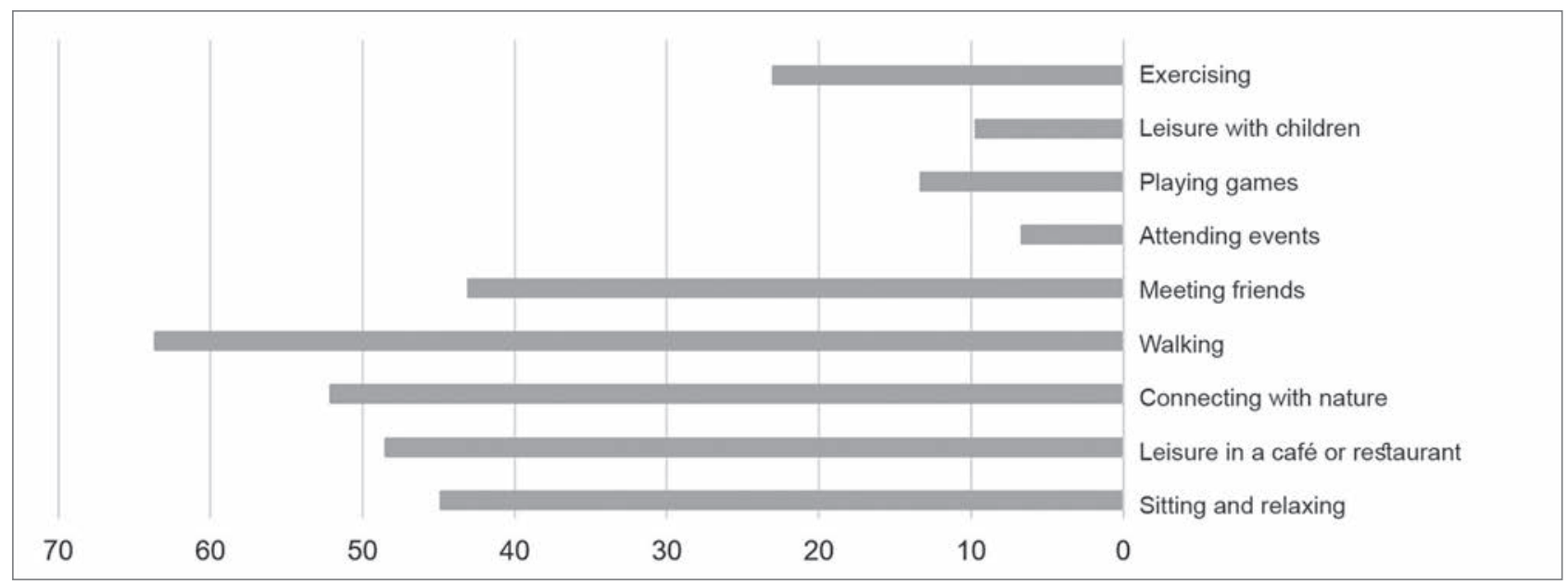

Figure 3: Activities chosen (multiple choice).

The consistency index $(\mathrm{CI})$ is calculated as:

$$
\mathrm{CI}=\frac{\lambda_{\max }-\mathrm{n}}{\mathrm{n}-1}
$$

and the consistency ratio $(\mathrm{CR})$ is calculated as:

$$
\mathrm{CR}=\frac{\mathrm{CI}}{\mathrm{RI}}
$$

where $\lambda_{\max }$ is the maximum eigenvalue of the matrix, $n$ is the matrix rank, and the random index (RI) is a randomly generated consistency index of a matrix, which relates to the matrix rank.

Saaty (2014) noticed the comparison as randomly generated when $C R$ reached 1 and the consistency as higher when $\mathrm{CR}$ reached 0 . Basically, $\mathrm{CR}<0.1$ was considered acceptable, whereas CR > 0.1 demonstrated a level of inconsistency and needed to be re-compared.

Based on the residents' opinions in the questionnaire, the factors' weights were calculated. The results obtained from the factors' weights are provided in Tables 7-9. The hierarchical analysis of the questionnaire was used to determine the critical items for assessing user preferences for the leftover space, using the weights.

\subsection{Results of questionnaires and personal interviews}

The weights of assessment factors given in Tables 7-9 indicate that relaxing had the highest weight for social intervention, topography had the highest weight for design intervention, and colour had the highest weight for aesthetic intervention. In weighing the social category (Figure 4), the two groups had similar priorities (table play and gallery). The choices were relaxing as the first priority, followed by leisure in café, playground, and exercising.

Interviews with the respondents indicated that the playground had the lowest priority for residents in the neighbourhood near the site, and that relaxing and restorative spaces were more vital to them. Comparison of the two options for sitting and relaxing intervention indicated that the urban furniture types were also important for the respondents. They paid attention to the form of the furniture and its flexibility. Although sitting and relaxing was not a priority of respondents in using open spaces (Figure 3), relaxing was a priority in the AHP comparison analysis. This could be due to the current inadequacy of urban furniture in Tehran. Respondents indicated that because having a restaurant in the neighbourhood is also interrelated to other factors, such as benches, these facilities can be the best way to become familiar with people in the neighbourhood and 
Table 7: Relative weights of evaluation items in the social category.

\begin{tabular}{lllllllll}
\hline & Social & & & & & \\
& Relaxing & Playground & Leisure in a café & Gallery & $\begin{array}{l}\text { Table-top } \\
\text { games }\end{array}$ & Sitting & Exercising \\
\hline Relaxing & 1 & 3.436 & 3.527 & 4.506 & 3.235 & 1.744 & 3.091 \\
\hline Playground & 0.291 & 1 & 1.453 & 3.392 & 2.868 & 1.928 & 2.098 \\
\hline Leisure in a café & 0.283 & 0.688 & 1 & 4.398 & 4.073 & 3.069 & 4.214 \\
\hline Gallery & 0.221 & 0.294 & 0.227 & 1 & 1.126 & 1.601 & 2.254 \\
\hline Table-top games & 0.309 & 0.348 & 0.246 & 0.888 & 1 & 1.826 & 2.091 \\
\hline Sitting & 0.573 & 0.450 & 0.325 & 0.624 & 0.547 & 1 & 3.664 \\
\hline Exercising & 0.323 & 0.476 & 0.237 & 0.443 & 0.478 & 0.272 & 1 \\
\hline
\end{tabular}

Note: Maximum eigenvalue $\left(\lambda_{\max }\right)=7.638 ; C l=0.106 ; C R=0.080$.

Table 8: Relative importance of evaluation items in the design category.

\begin{tabular}{llllll}
\hline & Design & & & & \\
\hline & Topography & Regular & Diversity & Density & Irregular \\
\hline Topography & 1 & 3.346 & 1.677 & 2.651 & 1.388 \\
\hline Regular & 0.298 & 1 & 1.519 & 1.265 & 1.712 \\
\hline Diversity & 0.596 & 0.658 & 1 & 2.893 & 2.128 \\
\hline Density & 0.377 & 0.790 & 0.345 & 1 & 2.134 \\
\hline Irregular & 0.720 & 0.584 & 0.469 & 0.468 & 1 \\
\hline
\end{tabular}

Note: Maximum eigenvalue $\left(\lambda_{\max }\right)=5.415$; consistency index $(\mathrm{Cl})=0.104$; consistency ratio $(\mathrm{CR})=0.093$.

Table 9: Relative importance of evaluation items in the aesthetic category.

\begin{tabular}{llllll}
\hline & Aesthetic & & & & \\
& Colour & Pattern & Sculpture & Installation & Mural \\
\hline Colour & 1 & 3.315 & 3.227 & 2.862 & 3.113 \\
\hline Pattern & 0.301 & 1 & 2.604 & 2.097 & 3.228 \\
\hline Sculpture & 0.309 & 0.383 & 1 & 1.322 & 3.245 \\
\hline Installation & 0.349 & 0.476 & 0.756 & 1 & 4.420 \\
\hline Mural & 0.321 & 0.309 & 0.308 & 0.226 & 1 \\
\hline
\end{tabular}

Note: Maximum eigenvalue $\left(\lambda_{\max }\right)=5.401$; consistency index $(C l)=0.100$; consistency ratio $(C R)=0.090$.

attract new restaurants. Working out consistently received the highest rating in the questionnaires (63\% of the residents use public open spaces to walk and $23 \%$ for sports activities), and active space for exercising was the least preferred intervention. As mentioned, respondents are more likely to walk, and they refuse to exercise in small spaces. Concerning the design category (Figure 5), topography was given the most weight, followed by diversity. In contrast, an irregular form for sites was chosen as the least important priority. Although variety in the level of space and type of vegetation was given priority in the design intervention subcategories, high vegetation density was the least preferred intervention. However, respondents did not favour designs below street level because they believed these would be turned into dumping grounds.
Unstructured interviews consistently indicated that high vegetation density creates a lack of visibility and social control, reducing safety and turning places into a crime location. A resident noted the existence of unsafe abandoned spaces with similar sizes in the neighbourhood. For this reason, she insisted on the importance of visibility and low vegetation density to ensure the safety of the space. According to four women, environmental factors, such as high vegetation density, also led to the disruption of norms. Therefore, the visibility of space was one of the most important variables for residents. Another woman said the following: "A few days ago, when I was passing through this area with my husband, we imagined this space as a small park with irregular geometry and a few benches". One of the respondents disagreed with all the options in the questionnaire. In his opinion, only design interventions with facilities, 


\begin{tabular}{|c|c|c|c|c|c|}
\hline Category & Scene & $\begin{array}{l}\text { AHP } \\
\text { weight }\end{array}$ & Category & Scene & $\begin{array}{l}\text { AHP } \\
\text { weight }\end{array}$ \\
\hline Relaxing & & 0.317 & $\begin{array}{l}\text { Table-top } \\
\text { games }\end{array}$ & & 0.0843 \\
\hline Leisure in a & & 0.205 & Gallery & & 0.0863 \\
\hline Playground & & 0.1778 & Exercising & & 0.0493 \\
\hline Sitting & & 0.0797 & & & \\
\hline
\end{tabular}

Figure 4: Relative importance of factors in the social category (illustration: authors).

\begin{tabular}{|c|c|c|c|c|c|}
\hline Category & Scene & $\begin{array}{l}\text { AHP } \\
\text { weight }\end{array}$ & Category & Scene & $\begin{array}{l}\text { AHP } \\
\text { weigh }\end{array}$ \\
\hline Topography & & 0.340 & Density & & 0.137 \\
\hline Diversity & & 0.221 & Irregular & & 0.115 \\
\hline Regular & & 0.185 & & & \\
\hline
\end{tabular}

Figure 5: Relative importance of factors in the design category (illustration: authors). 


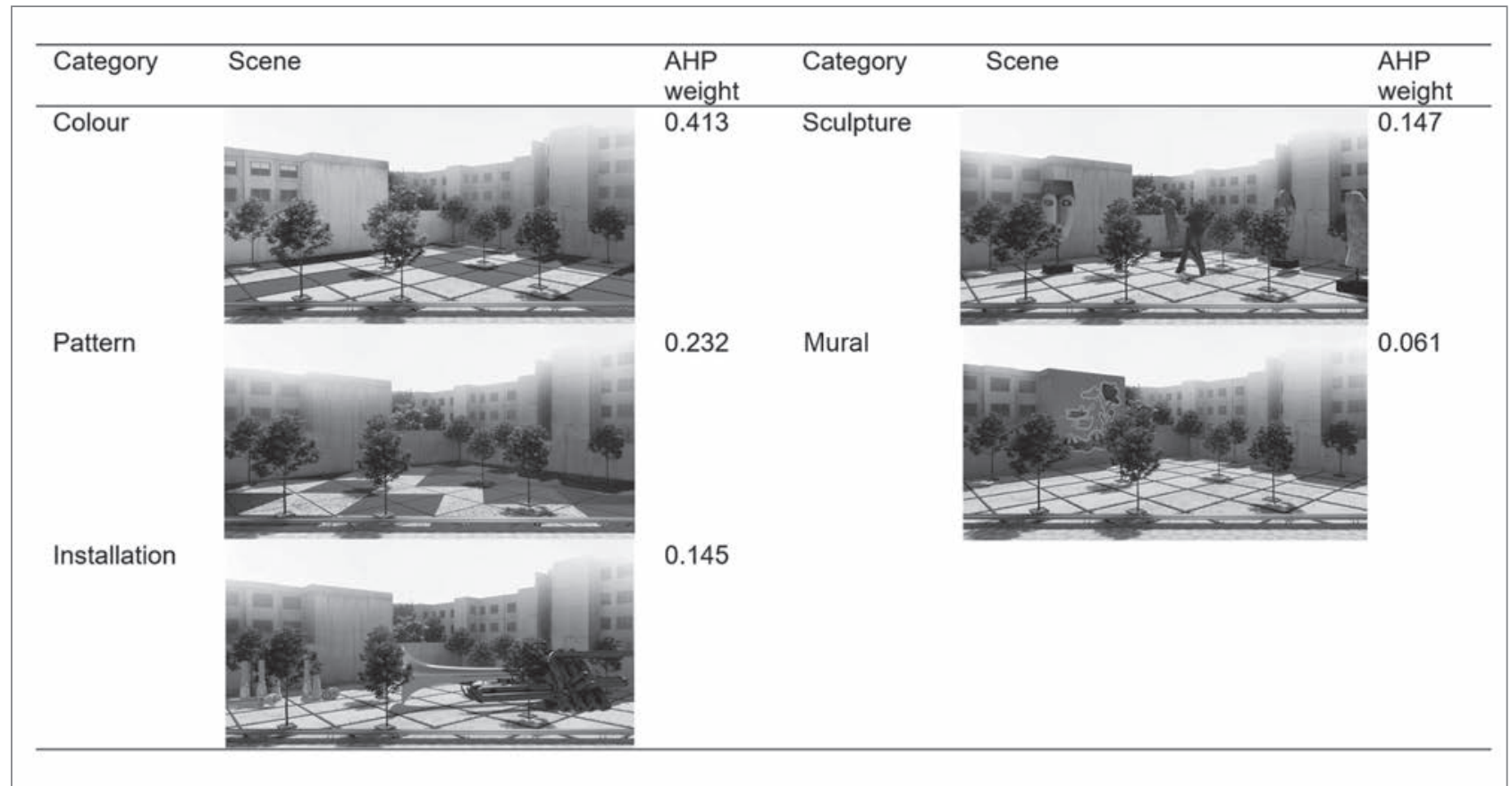

Figure 6: Relative importance of factors in the aesthetic category (illustration: authors).

such as a taxi station or a parking space, were suitable for this neighbourhood. Concerning the aesthetic category (Figure 6), colour had the most weight. In contrast, murals was chosen as the factor with the least priority. Although interviews showed that respondents liked the mural presented, they were not convinced that they would like one in their neighbourhood.

The difference in AHP weight in the two subcategories of colour and murals was raised in the respondents' interviews. According to a woman, the impact of colour on how we feel has been explored by researchers, but murals invoke an image associated with concepts and themes that may not suit her taste. A man mentioned: "Murals would be my first choice if I did not live in Tehran. Based on the low quality of the current murals in Tehran, this option will be my last priority. This reason also applies to not choosing a sculpture." Another man indicated that graffiti on a painted wall or floor can make it more attractive, but advertisements or writings on the wall cause a visual disturbance that is not easily removed.

Based on the questionnaire, because $81.21 \%$ of the respondents use miniparks in the evening and at night, darkness and lack of visibility may be another plausible reason for not selecting these types of interventions.

This study provides an excellent example of using AHP for evaluating user preferences. It employs AHP to discover residents' priorities in the design process and decision-making. Urban design, as an interdisciplinary process, needs to be incorporated with different dimensions. Therefore, deci- sion-makers and designers are required to have comprehensive knowledge of the related aspects. Both residents' preferences and experts' opinions show that deciding what to do and how much to do can only be effective if it is based on both descriptive and prescriptive analysis. When dealing with urban spaces, using minimal operations, considering safety and vandalism, may help them remain active. This would be an intervention approach following urban acupuncture. Although respondents expressed interest in aesthetic interventions, based on the current interventions going on in the city, they refused to select those categories as their priority. They seemed to be more interested in installations rather than sculptures because installations are temporary and changeable. In this regard, it is key to consider whether the intervention is permanent or temporary. Although the selected space is small, it is possible to effectively choose the type of intervention considering land uses around each pocket park. Despite their small size, these spaces can have different uses and play a vital role in changing the urban environment.

\section{Conclusion}

The results suggest that design interventions are the most preferred. However, the type of vegetation and its density should be considered in a way that does not compromise safety. In addition to respondents' interests in using various types of vegetation, emphasis was placed on planting deciduous and non-deciduous trees together. This type of planting can be valuable in creating diversity in different seasons. Considering these details can lead to minimal spatial interventions with 
high user preferences. In addition, respondents expressed interest in aesthetic interventions that are temporary and changeable. In this regard, it is key to consider whether an intervention is permanent or temporary. Moreover, the right type of urban furniture can improve the quality of space, which has a significant effect on residents' interaction with space. For new interventions to be effective as a catalyst of urban renovation, they must match the actual public preferences and priorities. This can be achieved by taking into account previous projects' experiences and selecting the best design interventions through categorizing and assessing their features.

In past decades, lost spaces were viewed negatively. However, findings have shown their potential to provide small-scale public space that can benefit residents and the entire city. Intervention on vacant land needs to be adapted to the characteristics of urban reality. In the future, it would make sense to carry out similar studies in other regions with different cultures and social contexts to see whether there is a significant difference between them. Furthermore, the views of experts and residents can be compared through further inquiries and surveys. Moreover, to evaluate residents' preferences regarding various interventions at the design phase, incorporating virtual reality into a questionnaire could prove useful.

Maryam Naghibi, Iran University of Science and Technology (IUST), School of Architecture and Environmental Design, Tehran, Iran E-mail: maryam_naghibi@arch.iust.ac.ir

Mohsen Faizi, Iran University of Science and Technology (IUST), School of Architecture and Environmental Design, Tehran, Iran E-mail: mfaizi@iust.ac.ir

Ahmad Ekhlassi, Iran University of Science and Technology (IUST), School of Architecture and Environmental Design, Tehran, Iran E-mail: ekhlassi@iust.ac.ir

\section{References}

Acebillo, J. A. (2006) Barcelona: Towards a new urban planning approach. Spatium, 13-14, pp. 55-59. DOI: 10.2298/SPAT0614055A

Ahern, J. (1999) Spatial concepts, planning strategies and future scenarios: A framework method for integrating landscape ecology and landscape planning. In: Klopatek, J. \& Gardner, R. (eds.) Landscape Ecological Analysis: Issues and Applications, pp. 175-201. New York, Springer. DOI: 10.1007/978-1-4612-0529-6

Aouad, D. (2016) Urban acupuncture as a tool for today's re-naturalization of the city: The non-constructible parcels of municipal Beirut through the case study of Saifi district. In: Rodrigues Couceiro da Costa, M. J., Roseta F., Couceiro da Costa, S. \& Pestana Lages, J. (eds.) Procedings of the EAAE ARCC 10th international conference (EAAE ARCC 2016), 15-18 June 2016, Lisbon, Portugal, pp. 629-636. Boca Raton, FL, CRC Press. DOI: 10.1201/9781315226255-96

Armstrong, H. (2006) Time, dereliction and beauty: An argument for landscapes of contempt. In: The landscape architect. IFLA conference papers May 2006, pp. 116-127. Canberra, Australian Institute of Landscape Architects.
Bahrami, B., Salehi, E., Jafari, H. \& Behbahani, H. I. (2012) Urban ecological landscape planning and design from garden city toward modern city - a case study: Tehran city in Iran. International Journal on Technical and Physical Problems of Engineering, 11(4), pp. 128-134.

Behzadfar, M., Abdi, F. \& Mohammadi, M. (2014) Promotion of the pedestrian-based capacity of major urban spaces of Farahzad village of Tehran. International Journal of Architectural Engineering \& Urban Planning, 24(1), pp. 45-55.

Bugaric, B. (2018) Urban acupuncture treatment implementing communication tools with youth in Ljubljana suburbs. Urbani izziv, 29, pp. 95-108. DOI: 10.5379/urbani-izziv-en-2018-29-supplement-006

Campelo, A. \& Fontenele, D. (2017) Sustainable development for recovering economic crisis: A possible solution for Brazil. In: Brebbia, C. A. \& Sendra, J. J. (eds.) The sustainable city XII (= WIT transactions on ecology and the environment 223), pp. 39-45. Ashurst, UK, WIT Press. DOI: $10.2495 /$ SC170041

Casagrande, M. (2015) From urban acupuncture to the third generation city. In: Revedin, J. (ed.) La ville rebelle. Démocratiser le projet urbain, pp. 1-22. Paris, Gallimard.

Casanova, H. \& Hernandez, J. (2015) Public space acupuncture. Barcelona, ACTAR.

Cerro, C. (2018) Developing solutions for dealing with water and food scarcity: Atmospheric water generator and urban farm tower. In: Advances in science and engineering technology international conferences, pp. 1-6. Piscataway, NJ, IEEE. DOI: 10.1109/ICASET.2018.8376754

Cheng, S. \& Niu, X. (2010) Urban acupuncture based on digital technology. In: Proceeding of 2nd international conference on information science and engineering, ICISE2010, pp. 4203-4206. Piscataway, NJ, IEEE. DOI: $10.1109 /$ ICISE.2010.5691876

Colorni, A., Ferretti, V., Lu, A., Oppio, A., Paruscio, V. \& Tomasini, L. (2017) Rethinking feasibility analysis for urban development: A multidimensional decision support tool. In: Gervasi, O., Murgante, B., Misra, S., Borruso, G., Torre, C. M., Rocha, et al. (eds.) Computational science and its applications - ICCSA 2017, pp. 624-638. Cham, Springer. DOI: 10.1007/978-3-319-62398-6

Daniel, T. C. (2001) Whither scenic beauty? Visual landscape quality assessment in the 21st century. Landscape and Urban Planning, 54(1-4), pp. 267-281. DOI: 10.1016/S0169-2046(01)00141-4

Daugelaite, A., Gražulevičiūte-Vileniške, I. \& Landauskas, M. (2018) Possibilities to apply the urban acupuncture concept in Kaunas: Social aspect. Landscape Architecture and Art, 13(13), pp. 18-27. DOI: 10.22616/j.landarchart.2018.13.02

de Solà-Morales, I. (2014) Terrain vague. In: Mariani, M. \& Barron, P. (eds.) Terrain vague interstices at the edge of the pale, pp. 40-46. New York, Routledge.

De Wit, S. I. (2014) Green galaxies: An interstitial strategy for restorative spaces. In: Cavallo, R., Komossa, S., Marzot, N., Berghauser-Pont, M. \& Kuijper, J. (eds.) New urban configurations, pp. 1072-1079. Amsterdam, IOS Press.

Drake, L. \& Lawson, L. J. (2014) Validating verdancy or vacancy? The relationship of community gardens and vacant lands in the U.S. Cities, 40(B), pp. 133-142. DOI: 10.1016/j.cities.2013.07.008

Dubeaux, S. \& Cunningham Sabot, E. (2018) Maximizing the potential of vacant spaces within shrinking cities, a German approach. Cities, 75, pp. 6-11. DOI: 10.1016/j.cities.2017.06.015

Enia, M. \& Martella, F. (2019) Reducing architecture: Doing almost nothing as a city-making strategy in 21st century architecture. Frontiers of Architectural Research, 8(2), pp. 154-163. DOI: 10.1016/j.foar.2019.01.006 
Folke, C. (2006) Resilience: The emergence of a perspective for social-ecological systems analyses. Global Environmental Change, 16(3), pp. 253-267. DOI: 10.1016/j.gloenvcha.2006.04.002

Franck, K. A. \& Stevens, Q. (2007) Loose space possibility and diversity in urban life. New York, Routledge. DOI: 10.4324/9780203799574

Gadanho, P. (2015) Uneven growth: Tactical urbanisms for expanding megacities. New York, The Museum of Modern Art.

Greenberg, M. \& Lewis, M. J. (2000) Brownfields redevelopment, preferences and public involvement: A case study of an ethnically mixed neighbourhood. Urban Studies, 37(13), pp. 2501-2514. DOI: $10.1080 / 00420980020080661$

Grifoni, R. C., Ottone, M. F. \& Prenna, E. (2017) Tomographic environmental sections for environmental mitigation devices in historical centers. Energies, 10(3), pp. 351-369. DOI: 10.3390/en10030351

Hands, D. E. \& Brown, R. D. (2002) Enhancing visual preference of ecological rehabilitation sites. Landscape and Urban Planning, 58(1), pp. 57-70. DOI: 10.1016/50169-2046(01)00240-7

Hofmann, M., Westermann, J. R., Kowarik, I. \& van der Meer, E. (2012) Perceptions of parks and urban derelict land by landscape planners and residents. Urban Forestry \& Urban Greening, 11(3), pp. 303-312. DOI: 10.1016/j.ufug.2012.04.001

Houghton, K., Choi, J. H. \& Lugmayr, A. (2015) From the guest editors: urban acupuncture. Journal of Urban Technology, 22(3), pp. 1-2. DOI: $10.1080 / 10630732.2015 .1087684$

Johnson, M. P., Hollander, J. \& Hallulli, A. (2014) Maintain, demolish, re-purpose: Policy design for vacant land management using decision models. Cities, 40, pp. 151-162. DOI: 10.1016/j.cities.2013.05.005

Kamvasinou, K. (2011) The public value of urban vacant land. Proceedings of the Institution of Civil Engineers: Municipal Engineer, 164(3), pp. 157-166. DOI: 10.1680/muen.9.00020

Kermani, A. A. (2016) Developing a framework for qualitative evaluation of urban interventions in Iranian historical cores. $A+B E$ Architecture and the Built Environment, 10, pp. 1-212. DOI: 10.7480/abe.2016.10

Khorshidifard, S. (2014) Hidden in plain sight: Tehran's empowering protean spaces. Doctoral thesis. Milwaukee, The University of Wisconsin-Milwaukee.

Kim, G. (2016) The public value of urban vacant land: Social responses and ecological value. Sustainability, 8(5), pp. 486-505.

DOI: $10.3390 /$ su8050486

Kim, E. J. \& Miller, P. (2017) Residents' perception of local brownfields in rail corridor area in the City of Roanoke: The effect of people's preconception and health concerns factors. Journal of Environmental Planning and Management, 60(5), pp. 862-882.

DOI: 10.1080/09640568.2016.1182898

Kim, G., Newman, G. \& Jiang, B. (2020) Urban regeneration: Community engagement process for vacant land in declining cities. Cities, 102(April), pp. 1-12. DOI: 10.1016/j.cities.2020.102730

Kremer, P., Hamstead, Z. A. \& McPhearson, T. (2013) A social-ecological assessment of vacant lots in New York City. Landscape and Urban Planning, 120, pp. 218-233. DOI: 10.1016/j.landurbplan.2013.05.003

Lafortezza, R., Corry, R. C., Sanesi, G. \& Brown, R. D. (2008) Visual preference and ecological assessments for designed alternative brownfield rehabilitations. Journal of Environmental Management, 89(3), pp. 257269. DOI: 10.1016/j.jenvman.2007.01.063

Lastra, A. \& Pojani, D. (2018) Urban acupuncture to alleviate stress in informal settlements in Mexico. Journal of Urban Design, 23(5), pp. 749-762. DOI: 10.1080/13574809.2018.1429902
Lerner, J. (2014) Urban acupuncture. Berlin, Springer. DOI: 10.5822/978-1-61091-584-7

Lokman, K. (2017) Vacancy as a laboratory: Design criteria for reimagining social-ecological systems on vacant urban lands. Landscape Research, 42(7), pp. 728-746. DOI: 10.1080/01426397.2017.1355446

Loukaitou-Sideris, A. (1996) Cracks in the city: Addressing the constraints and potentials of urban design. Journal of Urban Design, 1(1), pp. 91-103. DOI: 10.1080/13574809608724372

Lydon, M., Garcia, A. \& Duany, A. (2015) Tactical urbanism: Shortterm action for long-term change. Washington DC, Island Press. DOI: 10.5822/978-1-61091-567-0

Lynch, K. (1977) The image of the city. Cambridge, MA, MIT Press.

Map data (2020) Available at: https://www.google.com/maps/search/ Teheran,+Tehran,+Zafar+Street,+Iran/@35.6888203,51.4622624,10.75z (accessed 11 May 2020).

Mariani, M. \& Barron, P. (2014) Terrain vague: Interstices at the edge of the pale. New York, Routledge.

Marzi, M. \& Ancona, N. (2004) Urban acupuncture, a proposal for the renewal of Milan's urban ring road. 40th ISoCaRP congress, pp. 1-12. Milan, ISoCaRP.

Mondini, G., Fattinnanzi, E., Oppio, A. \& Bottero, M. (2018) Integrated evaluation for the management of contemporary cities. Berlin, Springer. DOI: 10.1007/978-3-319-78271-3

Nekhay, O. \& Arriaza, M. (2016) How attractive is upland olive groves landscape? Application of the analytic hierarchy process and GIS in southern Spain. Sustainability, 8(11), pp. 1-16. DOI: 10.3390/su8111160

Németh, J. \& Langhorst, J. (2014) Rethinking urban transformation: Temporary uses for vacant land. Cities, 40, pp. 143-150. DOI: 10.1016/j.cities.2013.04.007

Newman, G. \& Kim, B. (2017) Urban shrapnel: Spatial distribution of non-productive space. Landscape Research, 42(7), pp. 699-715. DOI: 10.1080/01426397.2017.1363877

Newman, G., Park, Y., Bowman, A. O. M. \& Lee, R. J. (2018) Vacant urban areas: Causes and interconnected factors. Cities, 72(B), pp. 421-429. DOI: 10.1016/j.cities.2017.10.005

Norouzian-Maleki, S., Bell, S., Hosseini, S.-B., Faizi, M. \& Saleh-Sedghpour, B. (2018) A comparison of neighbourhood liveability as perceived by two groups of residents: Tehran, Iran and Tartu, Estonia. Urban Forestry \& Urban Greening, 35, pp. 8-20. DOI: 10.1016/j.ufug.2018.08.004

Palmer, J. F. \& Hoffman, R. E. (2001) Rating reliability and representation validity in scenic landscape assessments. Landscape and Urban Planning, 54(1-4), pp. 149-161. DOI: 10.1016/S0169-2046(01)00133-5

Pearsall, H. \& Lucas, S. (2014) Vacant land: The new urban green? Cities, 40, pp. 121-123. DOI: 10.1016/j.cities.2013.10.001

Peng, S.-H. (2019) Landscape assessment for stream regulation works in a watershed using the analytic network process (ANP). Sustainability, 11(6), 1540. DOI: 10.3390/su11061540

Polat, S. \& Tümer Yıldız, H. Ö. (2019) Community engagement in developing urban design guidance for heritage sites: The case of Bursa, Turkey. Urban izziv, 30(2), pp. 70-84.

DOI: 10.5379/urbani-izziv-en-2019-30-02-001

Radstaak, S. (2012) Urban acupuncture in Rotterdam: As an apporach towards urban identity. Master's thesis. Wageningen, Wageningen University.

Rau, P.-L. P. \& Hutchison, D. (2019) Cross-cultural design. Berlin, Springer. 
Ruelle, C., Halleux, J. M. \& Teller, J. (2013) Landscape quality and brownfield regeneration: A community investigation approach inspired by landscape preference studies. Landscape Research, 38(1), pp. 75-99. DOI: $10.1080 / 01426397.2011 .647898$

Saaty, T. L. (1990) How to make a decision: The analytic hierarchy process. European Journal of Operational Research, 48(1), pp. 9-26. DOI: 10.1016/0377-2217(90)90057-I

Saaty, T. \& De Paola, P. (2017) Rethinking design and urban planning for the cities of the future. Buildings, 7(3), pp. 76-98.

DOI: 10.3390/buildings 7030076

Shieh, L. (2006) Urban acupuncture as a strategy for São Paulo. Master's thesis. Cambridge, MA, MIT University.

Steinitz, C. (2001) Visual evaluation models: Some complicating questions regarding memorable scenes. Landscape and Urban Planning, 54(1-4), pp. 283-287. DOI: 10.1016/S0169-2046(01)00142-6

Svobodova, K., Sklenicka, P., Molnarova, K. \& Salek, M. (2012) Visual preferences for physical attributes of mining and post-mining landscapes with respect to the sociodemographic characteristics of respondents. Ecological Engineering, 43, pp. 34-44.

DOI: 10.1016/j.ecoleng.2011.08.007

Thompson, C. W. (2002) Urban open space in the 21st century. Landscape and Urban Planning, 60(2), pp. 59-72.

DOI: 10.1016/S0169-2046(02)00059-2

Tortosa, L., Vicent, J. F., Zamora, A. \& Oliver, J. L. (2010) A neural network model to develop urban acupuncture. In: Setchi, R., Jordanov, I., Howlett R. J. \& Jain L. C. (eds.) Knowledge-based and intelligent information and engineering systems. KES 2010 (= Lecture notes in computer science 6276), pp. 31-40. Berlin, Springer.

DOI: 10.1007/978-3-642-15387-7_7

Trancik, R. (1986) Finding lost space. New York, Routledge.

Tveit, M., Ode, Å. \& Fry, G. (2006) Key concepts in a framework for analysing visual landscape character. Landscape Research, 31(3), pp. 229-255. DOI: 10.1080/01426390600783269

Unt, A. L. \& Bell, S. (2014) The impact of small-scale design interventions on the behaviour patterns of the users of an urban wasteland. Urban Forestry \& Urban Greening, 13(1), pp. 121-135.

DOI: 10.1016/j.ufug.2013.10.008

Unt, A. L., Travlou, P. \& Bell, S. (2014) Blank space: Exploring the sublime qualities of urban wilderness at the former Fishing Harbour in Tallinn, Estonia. Landscape Research, 39(3), pp. 267-286.

DOI: 10.1080/01426397.2012.742046

Wals, A. E. J. \& Wals, A. E. J. (2015) Social learning towards a sustainable world: Principles, perspectives, and praxis. Wageningen, Wageningen Academic Publishers. DOI: 10.1016/j.njas.2014.04.001

Zhang, Z., Meerow, S., Newell, J. P. \& Lindquist, M. (2019) Enhancing landscape connectivity through multifunctional green infrastructure corridor modeling and design. Urban Forestry \& Urban Greening, 38, pp. 305-317. DOI: 10.1016/j.ufug.2018.10.014

Zhao, M., Zhang, J. \& Cai, J. (2020) Influences of new high-rise buildings on visual preference evaluation of original urban landmarks: A case study in Shanghai, China. Journal of Asian Architecture and Building Engineering, 19(3), pp. 273-284. DOI: 10.1080/13467581.2020.1729769 